AperTO - Archivio Istituzionale Open Access dell'Università di Torino

\title{
Leaching potential of metallic elements from contaminated soils under anoxia
}

\section{This is the author's manuscript}

Original Citation:

Availability:

This version is available http://hdl.handle.net/2318/152183

since 2016-07-07T16:05:50Z

Published version:

DOI:10.1039/c3em00546a

Terms of use:

Open Access

Anyone can freely access the full text of works made available as "Open Access". Works made available under a Creative Commons license can be used according to the terms and conditions of said license. Use of all other works requires consent of the right holder (author or publisher) if not exempted from copyright protection by the applicable law. 
This is the author's final version of the contribution published as:

Ramona Balint; Gheorghe Nechifor; Franco Ajmone-Marsan. Leaching potential of metallic elements from contaminated soils under anoxia. ENVIRONMENTAL SCIENCE. PROCESSES \& IMPACTS. 16 (2) pp: 211-219.

DOI: $10.1039 / \mathrm{c} 3 \mathrm{em} 00546 \mathrm{a}$

The publisher's version is available at:

http://xlink.rsc.org/?DOI=C3EM00546A

When citing, please refer to the published version.

Link to this full text:

http://hdl.handle.net/2318/152183 


\title{
Leaching potential of metallic elements from contaminated soils under anoxia
}

\author{
Ramona Balint ${ }^{\mathrm{a}, \mathrm{b}, *}$, Gheorghe Nechifor ${ }^{\mathrm{a}}$, Franco Ajmone-Marsan ${ }^{\mathrm{b}}$
}

aDepartment of Analytical Chemistry and Environmental Engineering, Politehnica University of Bucharest, 011061, Bucharest, Romania

${ }^{\text {b} D i . S . A . F . A . ~-~ C h i m i c a ~ A g r a r i a, ~ U n i v e r s i t y ~ o f ~ T o r i n o, ~ V i a ~ L e o n a r d o ~ d a ~ V i n c i, ~ 44, ~ 10095, ~ G r u g l i a s c o, ~}$ Torino, Italy

*Corresponding author: R. Balint. E-mail address: balint.ramona@yahoo.com

Tel.: +39 0116708517; Mob.: +39 3397115445; Fax: +39 0116708692.

\section{Environmental Impact}

The higher frequency and intensity of extreme rainfall events, as well as the variations in precipitation patterns and intensities as a result of climate change may cause important shifts in soil hydrological regime. This could expose contaminated soils to significant variations in redox potentials possibly influencing metallic element behaviour and their potential transfer to other environmental compartments. This study shows that alternating soil redox conditions may enhance the release and redistribution of metals in more labile fractions. In particular, the presence of redox-sensitive minerals, such as chalcopyrite, in soils affected by mine tailings, could release significant amounts of $\mathrm{Cu}$ due to the alternating redox conditions and therefore have important environmental implications.

\section{Graphical abstract}

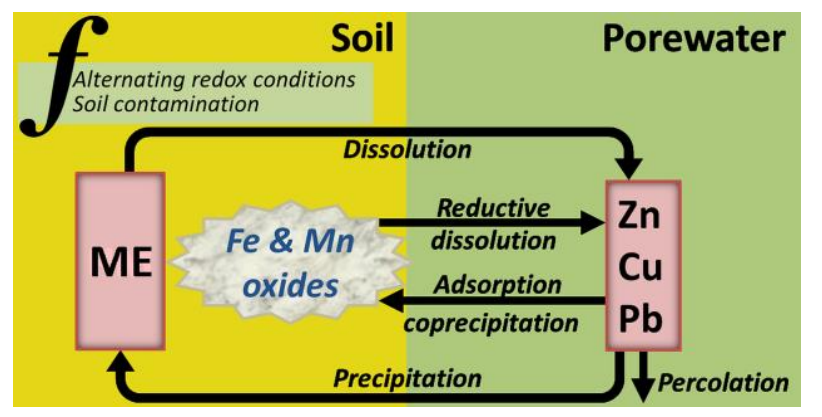

The alternation of redox cycles may play a higher role in the release, leaching and redistribution of metallic elements from contaminated soils with respect to oxidizing and reducing conditions alone.

\begin{abstract}
Understanding metallic element (ME) behaviour in soils subjected to alternating redox conditions is of significant environmental importance, particularly for contaminated soils. Although variations in the hydrological status of soils may lead to the release of $M E$, redox-driven changes in $M E$ dynamics are still not sufficiently understood. We studied the effects of alternating redox cycles
\end{abstract}


on the release, leaching and redistribution of $\mathrm{Zn}, \mathrm{Cu}$ and $\mathrm{Pb}$ in metal mine-contaminated and noncontaminated soils by means of a column experiment. Although the release of $\mathrm{Zn}$ was promoted by the onset of reductive conditions, successive redox cycles favoured metal partitioning in less labile fractions limiting its further mobilization. The release of $\mathrm{Cu}$ in soil porewaters and redistribution in the solid phase towards more labile pools were strongly dependent on the alternation between oxidizing and reducing conditions. In contaminated soils, the presence of chalcopyrite could have determined the release of $\mathrm{Cu}$ under oxic conditions and its relative immobilization under subsequent anoxic conditions. The behaviour of $\mathrm{Pb}$ did not seem to be influence by redox status, although higher concentrations in the column leachates with respect to soil porewaters suggested that alternating redox conditions could nonetheless result in substantial mobilization. This study provides evidence that the alternation of soil redox conditions may play a more important role in determining the release and leaching of metallic elements from soils with respect to reducing or oxidizing conditions considered separately.

\section{Introduction}

The negative impacts of climate change on human and environmental health have increased in many parts of the world, as weather-related hazards (floods, droughts and extreme temperatures) have become more frequent and more acute. The higher frequency and intensity of extreme rainfall events, as well as the variations in precipitation patterns and intensities - e.g. wetter winters with more frequent and more severe storm events ${ }^{1}$ - may cause changes in soil hydrological regime. In extreme cases, oxic topsoils may become anoxic due to water saturation for a more or less prolonged period of time. At the onset of anaerobiosis a series of reactions occur that involve electron acceptors other than oxygen. When $\mathrm{Mn}$ and Fe are reduced, they become several order of magnitude more soluble than their oxidized compounds and may rapidly release the elements that are associated to them to the soil solution. ${ }^{2,3}$

As soils generally serve as a sink for numerous contaminants like pesticides, dioxins, agricultural chemicals, and metallic elements (ME), submergence may result in the release of these pollutants from the soil to other environmental compartments. ${ }^{4}$ While the effect of water saturation on the release of ME from riverine, agricultural and urban soils is well documented, ${ }^{5-9}$ less information is available about mine and smelter-affected areas. ${ }^{10,11}$

Intermittent flooding/drying and the consequent reductive and oxidative conditions may affect the chemical speciation, bioavailability, toxicity and mobility of metals in the soil. ${ }^{2,3}$ It is generally 
agreed that the release of $\mathrm{ME}$ into solution can be influenced by wet/dry cycles, ${ }^{12,13}$ but $\mathrm{ME}$ mobilization can also be counteracted by their stabilization due to other processes that take place under reducing conditions. Contradictory information regarding the effect of intermittent submergence on the behaviour of ME in pore water has been reported. In acid soils under anoxic conditions, ME can be readsorbed on soil particles due to the increase in $\mathrm{pH}^{14}$ and, in the case of highly reduced soils, metals can be immobilized by precipitation as sulphides and carbonates. ${ }^{15}$ Soil redox oscillations may also increase the crystallinity of Fe oxides enhancing the fixation of some ME into their structure. ${ }^{16}$ Contrasting results were also obtained for the partitioning of ME between phases with variable lability, in flooded soils. While Kashem and Singh ${ }^{17}$ reported that the addition of organic matter (OM) favoured the partitioning of ME in more labile pools, Huang et al. ${ }^{18}$ showed that OM amendment of submerged soils caused a decrease in oxidizable, and Fe and $\mathrm{Mn}$ oxide-bound $\mathrm{Cu}$ leading to a relative increase in more stable forms.

This study aims at elucidating the influence of redox oscillations on the release and mobility of ME and the changes in their chemical forms in mine-impacted soils. As mining activities frequently take place in mountainous river valleys where the probability of flash floods is higher than in plains, it is necessary to understand ME behaviour in these soils in order to evaluate the possible effects of climate change on the environmental hazards posed by ME.

We hypothesised that soil metals released into solution under reducing conditions may be subsequently translocated during water drainage and potentially leached from the soil and/or redistributed in the more labile metal pools. To test this hypothesis we evaluated changes in $\mathrm{Cu}$, $\mathrm{Pb}$, and $\mathrm{Zn}$ concentrations in soil pore waters and leachates from soil columns subjected to a series of oxic/anoxic redox cycles. Metal distribution before and after the incubation, was evaluated by sequential extraction.

\section{Materials and methods}

\section{Soil Sampling}

Contaminated soil samples were collected from the river valley located in Bălan, Harghita county, Romania (Fig. 1). Mixed Cu-Pb-Zn deposits have been mined in this area and during the long period of mining activity, the atmosphere, waters and soils have been contaminated with ME. ${ }^{19}$ Soils were sampled from areas chosen at increasing distance from the main contamination source, the preparation plant where $\mathrm{Cu}$ flotation had been carried out, to compare different degrees of contamination. Each sample was composed of a series of subsamples collected over an area of 400 
$\mathrm{m}^{2}$ and adequately homogenized. The soil subsamples of a highly contaminated area (HCN) were collected approximately $150 \mathrm{~m}$ uphill from the contamination source, while a less contaminated area (LCN) was sampled about $5 \mathrm{~km}$ downhill from the preparation plant. A non-contaminated soil (NCN), developing on a similar bedrock, was sampled from an area near the town of Izvorul Mureşului, approximately $8 \mathrm{~km} \mathrm{SW}$ of the source of contamination. This sample was taken as reference soil representing background values for ME concentrations. All samples were air-dried, gently crushed to pass through a $2 \mathrm{~mm}$ sieve. A small portion of each sample was further ground to $<0.5 \mathrm{~mm}$ for pseudo-total metal analysis.

\section{General Soil Properties}

Physical and chemical soil properties were determined using standard methods. ${ }^{20}$ Soil $\mathrm{pH}$ was measured potentiometrically in $1 \mathrm{M} \mathrm{KCl}$ using a 1:2.5 soil:solution ratio. Particle-size analysis of the soil material $(<2 \mathrm{~mm}$ ) was conducted by the sieve-pipette method after dispersion with sodium hexametaphosphate. Total $\mathrm{C}$ and $\mathrm{N}$ contents of the bulk soil were measured on ground subsamples $(<0.5 \mathrm{~mm}$ ) by dry combustion (NA2100, CE Instruments, Milan, Italy). Since the soil material was free of carbonates, total $\mathrm{C}$ was considered as organic C. Pseudo-total metal content was determined by microwave-assisted aqua regia $\left(\mathrm{HCl}: \mathrm{HNO}_{3}, 3: 1\right.$ solution) digestion (MILESTONE Start D). Metallic element extraction with dithionite-citrate-bicarbonate (DCB) and ammonium oxalate (AO) were performed as described by Mehra and Jackson. ${ }^{21}$ Although these extractions were originally intended for the determination of Fe oxides, they can nevertheless be used to evaluate metal contents associated with oxides and OM (e.g. adsorbed, co-precipitated, complexed) and their potential release from soils under anoxic conditions. ${ }^{22,23}$ All extracts were analysed in duplicate for $\mathrm{Cu}, \mathrm{Fe}$, and $\mathrm{Mn}$ concentration by flame atomic absorption spectrometry (FAAS, Perkin-Elmer 400).

\section{Column Experiment}

Each soil was packed (in duplicate) into PVC columns $70 \mathrm{~cm}$ in height and $7 \mathrm{~cm}$ in diameter as sketched in Fig. 2. Soil columns were exposed to a series of four 7-day anoxic-oxic cycles. Each cycle was composed of 5 days anoxic conditions during which the soils were oversaturated with a $10 \mathrm{mM} \mathrm{CaCl} 2+3 \mathrm{mM}$ lactose solution, followed by column drainage for 2 days. Prior to column leaching (i.e. on the $5^{\text {th }}$ day of each anoxic period), soil pore waters were extracted by Rhizon samplers installed at a depth of 10 and $30 \mathrm{~cm}$ (UR and LR, respectively) from the soil surface, while soil leachates were collected from the bottom of the column during drainage. More details of the column setup and soil packaging have been provided elsewhere. ${ }^{24}$ Total metal ( $\mathrm{Cu}, \mathrm{Pb}$, and $\mathrm{Zn}$ ) 
contents in the solutions were analyzed by FAAS.

After four cycles of flooding and draining the soils were carefully extracted from the columns, and three $10 \mathrm{~cm}$ soil sections sampled at depths corresponding to the upper (U) and lower (L) Rhizons, and bottom of the column (B). All soils were dried at $40^{\circ} \mathrm{C}$ prior to further analysis.

\section{Metal Fractionation}

Metal fractionation on all soil samples was performed in triplicate using the modified BCR sequential extraction procedure as described by Rauret et al. ${ }^{25}$ This method was used to extract and quantify metals that are contained in fractions generally described as exchangeable (F1), bound to Fe-Mn oxides (F2), bound to organic matter (F3) and residual (F4). Total $\mathrm{Cu}, \mathrm{Pb}$ and $\mathrm{Zn}$ in each extract was determined by FAAS. Recoveries were calculated as the ratio of the sum of ME contents in each BCR fraction to pseudo-total ME concentrations determined on the bulk soil. In all soils, $\mathrm{Zn}, \mathrm{Cu}$ and $\mathrm{Pb}$ recoveries ranged between $83-103,74-101$ and 75-101\% of the pseudototal concentrations in the initial soils, respectively. The influence of experimental conditions on the partitioning of ME was evaluated by comparing with ME distribution in the initial soils (I) not subjected to the redox cycling.

\section{Results and discussion}

\section{Soil Properties}

Soil texture, $\mathrm{pH}, \mathrm{C} / \mathrm{N}$ ratio, and pseudo-total $\mathrm{Cu}, \mathrm{Pb}$, and $\mathrm{Zn}$ concentrations are reported in Table 1. The soils are acid with a rather coarse texture that could favour ME loss from the soil to the water table. In the studied area, the main sources of $\mathrm{Cu}, \mathrm{Pb}$, and $\mathrm{Zn}$ are chalcopyrite $\left(\mathrm{CuFeS}_{2}\right)$, galena (PbS), and sphalerite ((Zn,Fe)S), respectively. ${ }^{26}$ Therefore, due to past exploration and exploitation works, elements from these minerals were released into the environment. ${ }^{27}$ The soils sampled from the mining areas ( $\mathrm{HCN}$ and $\mathrm{LCN}$ ) had relatively higher amounts of all metals, in particular $\mathrm{Cu}$, with respect to the soil from the reference area (NCN). The total concentration of $\mathrm{Cu}, \mathrm{Pb}$, and $\mathrm{Zn}$ (Table 1), however, was not indicative of significant contamination. The ME contents in the contaminated soils exceeded the Romanian legislative recommended concentrations (Order no. 756/1997), but generally did not exceed the threshold alert or intervention values.

Metallic elements are known to be associated to $\mathrm{Fe}$ and $\mathrm{Mn}$ oxides by binding or coprecipitation. ${ }^{28,29}$ This has been especially observed in Fe and $\mathrm{Mn}$ nodules which form in wetland soils under alternating redox conditions. ${ }^{30,31}$ Therefore, DCB and AO soil extracts do not 
only estimate the contents of crystalline and amorphous Fe/Mn oxides in the soils, respectively ${ }^{21}$ but can give an appraisal of the amount of oxide-associated ME. ${ }^{23}$

Table 2 reports the amounts of ME presumably associated with Fe/Mn oxides and potentially subject to release during their reductive dissolution. A significant proportion of total Cu present in contaminated soils $(\approx 54 \%)$ was extractable in $\mathrm{AO}$, suggesting that $\mathrm{Cu}$ is predominantly bound to short-range aluminosilicates and organo-mineral complexes. ${ }^{32}$ In contrast, only $35 \%$ of total $\mathrm{Cu}$ was AO-extractable in NCN suggesting that the potential for metal mobilization due to reductive dissolution of amorphous $\mathrm{Fe}$ and $\mathrm{Mn}$ oxides or $\mathrm{OM}$ oxidation under redox conditions is lower in non-contaminated soils. The higher contents of AO- with respect to DCB-extractable $\mathrm{Cu}$ in all soils suggest that this element is not entirely associated to the mineral phases solubilized by reductive dissolution. However, we cannot exclude that some Cu might be present in mineral forms that are readily mobilized at the $\mathrm{pH}$ of $\mathrm{AO}$ extraction $(\mathrm{pH} 3)$.

Most of the $\mathrm{Zn}(\approx 52 \%)$ and some of the $\mathrm{Pb}(11-20 \%)$ contained in HCN and LCN was extractable in $D C B$, though the proportion of these metals also extractable in AO was limited. In fact, only about 9-16\% of $\mathrm{Zn}$ was AO-extractable while the concentration of $\mathrm{Pb}$ was below detection limit. In NCN the proportion of $\mathrm{Zn}$ in the DCB extract was slightly greater with respect to the contaminated soils, thus suggesting the distribution of $\mathrm{ME}$ in different pools may be more indicative of their potential release from soil subjected to alternating redox conditions, with respect to total concentrations. These results also suggest that $\mathrm{Zn}$ may be mainly associated with crystalline oxides of $\mathrm{Fe}$ and $\mathrm{Mn}$ as reported by Van Laer et al. $^{33}$ and Tack et al. ${ }^{34}$

\section{Column Experiments}

The mobility and transport of ME in soils was assessed as a function of alternating redox cycles by sampling and analysing soil pore waters and leachates. With successive redox cycles mean $\mathrm{pH}$ values of soil leachates tended to increase in HCN, LCN, and NCN from 6.2, 5.8, and 6.9 respectively, to 7.1 , indicative of the typical increase in soil $\mathrm{pH}$ under reductive conditions. The column setup used did not allow for measurement of redox potentials during the experiment. However, the increase in Fe and Mn concentrations in soil porewaters as a result of the reductive dissolution of Fe and Mn (hydr)oxides was used as a proxy for reducing conditions, as previously discussed in Balint et al. ${ }^{24}$ Moreover, we evaluated the change in soil Eh under anoxic conditions in a preliminary batch experiment. Under non-limiting electron donor conditions (lactose addition), Eh rapidly decreased to values of $-150,-189$, and $-216 \mathrm{mV}$ within 2 days of anoxic incubation for HCN, LCN, and NCN respectively. 
Significant amounts of $\mathrm{Zn}$ were readily released in solution during the first redox cycle and continued to increase reaching highest concentrations during the second reductive phase for $\mathrm{HCN}$ and LCN (Fig. 3). The significant amounts of Zn associated with Fe and Mn oxyhydroxides (Table 2) suggest that the increasing trend in porewater $\mathrm{Zn}$ concentrations under reducing conditions may be related to the reductive dissolution of these metal oxides. This is supported by our previous findings on the reductive dissolution of $\mathrm{Mn}$ and Fe oxyhydroxides from these soils ${ }^{24}$ that showed a similar increase in porewater $\mathrm{Mn}$ followed by Fe solubilisation, in line with their different reduction potentials. In fact, the principal control mechanism for $\mathrm{Zn}$ in wetland soils is considered to be dependent on the hydrous Fe and Mn oxides. ${ }^{31}$ Van Laer et al. ${ }^{33}$ also attributed the mobilization of $\mathrm{Zn}$ in waterlogged soils to the reductive dissolution of Fe and $\mathrm{Mn}$ oxides which may have occluded or sorbed ME. While some authors have shown that $\mathrm{Zn}$ is substantially fixed by soils rich in Fe oxides, ${ }^{35}$ Sipos et al. ${ }^{36}$ found that $\mathrm{Zn}$ is less immobilized by soil mineral phases with respect to $\mathrm{Cu}$ and $\mathrm{Pb}$. In our experiment, after an initial increase, soil porewater $\mathrm{Zn}$ concentrations tended to decrease with each subsequent redox cycles (Fig. 3). Successive reductive dissolution of Fe and $\mathrm{Mn}$ oxyhydroxides could have resulted in the exposure of new sorption sites on the surface of soil minerals which may act as a sink for $\mathrm{Zn} .{ }^{13}$ Coprecipitation of $\mathrm{Zn}$ with newly formed oxides under oxic conditions could also have limited the subsequent release of this ME during anoxic conditions. Similar results were obtained by Contin et al. ${ }^{16}$ who observed the stabilization of $\mathrm{Zn}$ and other ME in soils amended with Fe-rich waste subjected to similar redox alternations. The aging of Zn-containing coprecipitates could have further contributed to $\mathrm{Zn}$ stabilization as suggested by the findings of Davranche and Bollinger. ${ }^{28}$ These processes could also explain the relatively low and decreasing concentrations of $\mathrm{Zn}$ in the oxic soil leachates with successive redox cycles (Fig. 3). Although NCN showed similar trends with respect to HCN and LCN, the extent of Zn release was less pronounced even though this soil had similar amounts of $\mathrm{Zn}$ associated with the reducible Fe and $\mathrm{Mn}$ oxides (Table 2). This could be due to the higher clay and silt content in NCN with respect to $\mathrm{HCN}$ and LCN (Table 1), which might have led to a more pronounced metal sorption under reducing conditions.

As for $\mathrm{Zn}$, the release of $\mathrm{Cu}$ into soil solution was favoured by the onset of reductive conditions, with highest porewater concentrations observed during the first redox cycle in contaminated and, to a lesser extent, non-contaminated soils (Fig. 3). The limited release of $\mathrm{Cu}$ in NCN could be attributed to lower total (Table 1 ) and oxide-associated (Table 2) contents with respect to contaminated soils. With successive redox cycles porewater $\mathrm{Cu}$ concentrations tended to decrease 
steadily reaching values close to or below detection limits in the fourth reductive phase. This may be due to the decreasing $\mathrm{Cu}$ solubility with increasing $\mathrm{pH}$, as generally observed in acidic soils under reducing conditions. Moreover, recent studies by Biasioli et al., ${ }^{12}$ Fulda et $a .^{37}$ and Matocha et $a l .{ }^{38}$ have shown that, under anoxic conditions, $\mathrm{Cu}(\mathrm{II})$ can be reduced to $\mathrm{Cu}(\mathrm{I})$ or $\mathrm{Cu}(0)$ and subsequently stabilized as insoluble $\mathrm{Cu}(\mathrm{I})$-humic acids complexes or precipitated as $\mathrm{Cu}_{2} \mathrm{O}$. Huang et al. ${ }^{18}$ presented similar results for OM-amended paddy soils. They attributed the decrease in $\mathrm{Cu}$ release to the degradation of dissolved organic carbon (DOC) with which $\mathrm{Cu}$ is usually complexed, or to the formation of less soluble $\mathrm{Cu}$ minerals. Moreover, in our experiment, the decrease in $\mathrm{Cu}$ release from soils during anoxic periods might have been due to the addition of lactose which served as the main electron donor and diminished the possibility of oxidation of organometallic complexes present in the soil. The behaviour of $\mathrm{Cu}$ in the contaminated soils could also be explained by the presence of chalcopyrite $\left(\mathrm{CuFeS}_{2}\right)$ and other $\mathrm{Cu}$-bearing minerals from mine tailings. In oxic soils, the surface of chalcopyrite is generally covered with a layer of Cu-rich sulphides, sulphates and oxides $\left(\mathrm{Cu}_{2} \mathrm{~S}, \mathrm{CuS}, \mathrm{CuSO}_{4}\right.$ and $\left.\mathrm{Cu}_{2} \mathrm{O}\right)$. The dissolution of $\mathrm{Cu}$-containing salts present in the outer layer of this mineral could have contributed to the relatively high $\mathrm{Cu}$ concentrations in porewaters upon initial flooding. However, the contrasting increase in leachate $\mathrm{Cu}$ concentrations with successive cycles suggests that other mechanisms, apart from dissolution, predominate during the oxic phases. In fact, significant $\mathrm{Cu}$ leaching might be due to the oxidation of chalcopyrite under oxic conditions as reviewed by Li et al. ${ }^{39}$ The absence of mine tailings in noncontaminated soils would explain why this increasing trend was not observed in NCN.

Although the release of $\mathrm{Pb}$ under anoxic conditions was probably related to the reductive dissolution of Fe and $\mathrm{Mn}$ oxides, no clear trend was observed with successive redox cycles in all soils analysed. This was probably due to relatively low amounts of $\mathrm{Fe}$ and $\mathrm{Mn}$ oxide-associated $\mathrm{Pb}$ in the soils (Table 2). Moreover, the favourable readsorption of $\mathrm{Pb}$ on soil mineral constituents at near-neutral $\mathrm{pH}^{29}$ could have further limited its release with successive redox cycles. However, contrasting results on the release of $\mathrm{Pb}$ from flooded soils have been reported. While $\mathrm{Ma}$ and Dong ${ }^{40}$ showed that $\mathrm{Pb}$ concentrations in pore water of a highly contaminated soil decreased with incubation time, Grybos et al. ${ }^{41}$ observed that $\mathrm{Pb}$ release in an organic, wetland soil increased both under anoxic and oxic conditions. Higher $\mathrm{Pb}$ concentrations were generally observed in the soil leachates with respect to the porewaters throughout the experiment, suggesting that this metal is nonetheless potentially lost from soils subjected to alternating redox conditions. 


\section{BCR Sequential Extraction}

It is widely accepted that the mobility, transport and bioavailability of ME in soils does not only depend on their total contents but also on their partitioning between more or less labile pools. The distribution of ME in operationally-defined fractions of decreasing lability (F1-F4) resulted in the partitioning of total metal contents between soil phases generally referred to as exchangeable, reducible, oxidizable and residual pools, respectively. In general, it appears that metal partitioning was affected by the reduction-oxidation cycles. Although $\mathrm{Zn}$ release into solution during the column experiments was mainly attributed to the reductive dissolution of Fe and $\mathrm{Mn}$ oxides, only a small decrease in the amount of $\mathrm{Zn}$ in the reducible fraction (F2) with respect to the initial soils was observed after the successive redox cycles (Table 3 and Fig. 4). Similarly, $\mathrm{Zn}$ in the exchangeable fraction (F1) tended to decrease with redox cycling, while little differences were observed for $\mathrm{Zn}$ contents in the oxidizable fraction (F3; Table 3). The concentrations of Zn released into solution during the reductive phases (Fig. 3) were however between 1 and 2 orders of magnitude smaller than $\mathrm{Zn}$ contents in the exchangeable and reducible fractions (Table 3 ). Nonetheless, in all soils alternating redox cycling resulted in an increase in the proportion of $\mathrm{Zn}$ in the residual fraction, at the expense of the exchangeable pool (F4; Fig. 4) possibly corroborating the decreasing trend in $\mathrm{Zn}$ leached from the columns with successive redox cycles. These results suggest that alternating redox conditions may favour the redistribution of $\mathrm{Zn}$ from exchangeable and reducible forms to less labile, more retained forms. A similar decrease in exchangeable and carbonate-associated fractions of $\mathrm{Zn}$, and an increase in the oxidizable fraction was reported for soils incubated under a wetting/drying regime. ${ }^{42}$

After incubation, $\mathrm{Cu}$ in the contaminated soils presented a relative increase in the proportion found in exchangeable forms, particularly in the lower sections of the column (Fig 4), in line with our previous hypothesis that soluble $\mathrm{Cu}$ salts from mine tailings may play an important role in determining $\mathrm{Cu}$ mobility. This is in agreement with the steady increase in leached $\mathrm{Cu}$ concentrations with successive redox cycling (Fig. 3). Alternating redox conditions did not seem to have an effect on $\mathrm{Cu}$ redistribution between different fractions in non-contaminated soils where $\mathrm{Cu}$ was mainly distributed in the residual $(F 4)$ and, to a minor extent, reducible (F2) fractions. However, in contaminated soils, redox cycling led to lower metal contents in reducible and oxidizable fractions (Table 3), with respect to the initial soils. These results are in disagreement with the results obtained by Han et al. ${ }^{42}$ and Zheng and Zhang ${ }^{9}$ who report a redistribution of $\mathrm{Cu}$ from more labile to more stable forms in ME-spiked soils subjected to wet/dry conditions. 
Similarly, Businelli et al. ${ }^{43}$ observed a redistribution of metals with time from organically-bound to the residual fractions, particularly for $\mathrm{Cu}$ and $\mathrm{Zn}$, in a compost amended landfill covering soil. Moreover, the results obtained by McLaren and Crawford ${ }^{44}$ who developed a similar fractionation method suggested that the distribution of $\mathrm{Cu}$ between soil constituents might be influenced by the association with free $\mathrm{Mn}$ (hydr)oxides, as indicated by the DCB and AO extractions (Table 2).

In both contaminated and non-contaminated soils, most of the $\mathrm{Pb}$ was found in reducible and residual fractions in approximately equal proportions (Fig. 4), while Pb contents in exchangeable and oxidizable pools were below detection limits (Table 3). In all cases, no important differences were observed in the distribution of $\mathrm{Pb}$ between these fractions as a function of alternating redox conditions. Pueyo et al. ${ }^{45}$ also found $\mathrm{Pb}$ partitioned mainly in the reducible and residual fractions with little change in their distribution as a function of time. The significant $\mathrm{Pb}$ contents in the labile reducible fraction (about $40-50 \%$ of the total content) suggest that important amounts of this metal can be potentially released into the environment from soils subject to alternating redox conditions. However, the amounts of $\mathrm{Pb}$ released into solution during the successive redox cycles (Fig. 3) were rather limited (only about $1 \%$ of the total $\mathrm{Pb}$ content) suggesting that $\mathrm{Pb}$ lability may not necessarily be affected by redox cycles.

\section{Conclusions}

The behaviour of $\mathrm{Cu}, \mathrm{Pb}$ and $\mathrm{Zn}$ under alternating soil redox conditions revealed that metal contaminants can be susceptible to release or redistribution in forms which are more or less prone to subsequent leaching. We hypothesized that in redox dynamic environments the potential mobilization of ME from contaminated soils may pose a serious environmental hazard. We observed that the alternation of soil redox conditions may play a more important role in determining $\mathrm{ME}$ mobilization with respect to reducing or oxidizing conditions considered separately. The release and redistribution of $\mathrm{Zn}$ in pools with reduced lability seemed to be controlled by the reductive dissolution and oxidative reprecipitation of Fe and $\mathrm{Mn}$ oxides. Copper dynamics, on the other hand, seemed to be influenced by the presence of redox-sensitive $\mathrm{Cu}$ bearing minerals in contaminated soils. The mobility of $\mathrm{Cu}$ was probably determined by the dissolution of chalcopyrite under oxidizing conditions and relative stability under anoxia. Although the behaviour of $\mathrm{Pb}$ did not seem to follow a clear trend with redox cycling, the higher concentrations in the leachates with respect to soil porewaters suggested that alternating redox conditions could have favoured $\mathrm{Pb}$ mobility. In conclusion, this study pointed out the potential 
hazards posed by temporary changes in redox status of mine-tailing contaminated soils, and highlighted the risk of $\mathrm{Cu}$ leaching from $\mathrm{Cu}$-bearing minerals due to alternating reductive and oxidative conditions.

\section{Acknowledgements}

This study was carried out at Di.S.A.F.A. - Chimica Agraria, University of Turin, and was co-funded by Politehnica University of Bucharest through the Sectoral Operational Programme Human Resources Development 2007-2013, Financial Agreement POSDRU/107/1.5/S/76813. The help of

E. Buratto with the sample preparation and analytical work is gratefully acknowledged.

\section{References}

1 IPCC, Climate Change 2007: Synthesis Report, Cambridge, 2007.

2 T. Borch, R. Kretzschmar, A. Kappler, P. Van Cappellen, M. Ginder-Vogel, A. Voegelin and K. Campbell, Environ. Sci. Technol., 2010, 44, 15-23.

3 R. Carrillo-González, J. Šimůnek, S. Sauvé and D. Adriano, Advances in Agronomy, 2006, 91, 111-178.

4 K. Alderman, L. R. Turner and S. Tong, Environ. Int., 2012, 47, 37-47.

5 M. Biasioli and F. Ajmone-Marsan, J. Environ. Monitor., 2007, 9, 862-868.

6 G. Du Laing, B. Vandecasteele, P. De Grauwe, W. Moors, E. Lesage, E. Meers, F. M. G. Tack and M. G. Verloo, J. Environ. Monitor., 2007, 9, 449-455.

7 L. Madrid, E. Diaz-Barrientos, E. Ruiz-Cortés, R. Reinoso, M. Biasioli, C. M. Davidson, A. C. Duarte, H. Grčman, I. Hossack, A. S. Hursthouse, T. Kralj, K. Ljung, E. Otabbong, S. Rodrigues, G. J. Urquhart and F. Ajmone-Marsan, J. Environ. Monitor., 2006, 8, 1158-1165.

8 L. Van Laer and E. Smolders, Environ. Sci.: Processes Impacts, 2013, 15, 1181-1190.

9 S. Zheng and M. Zhang, J. Environ. Sci., 2011, 23, 434-443.

10 D. Kossoff, K. A. Hudson-Edwards, W. E. Dubbin and M. Alfredsson, Appl. Geochem., 2012, 27, 562-576.

11 I. Popescu, M. Biasioli, F. Ajmone-Marsan and R. Stănescu, Chemosphere, 2013a, 90, 820-826.

12 M. Biasioli, J. K. Kirby, G. M. Hettiarachchi, F. Ajmone-Marsan and M. J. McLaughlin, J. Environ. Qual., 2010, 39, 2047-2053.

13 M. Florido, F. Madrid and F. Ajmone-Marsan, Water, Air, Soil Pollut., 2011, 217, 149-156.

14 M. A. Kashem and B. R. Singh, Commun. Soil Sci. Plant Anal., 2004, 35, 1435-1456. 
15 G. Du Laing, J. Rinklebe, B. Vandecasteele, E. Meers and F. M. G. Tack, Sci. Total Environ., 2009, 407, 3972-3985.

16 M. Contin, C. Mondini, L. Leita and M. De Nobili, Geoderma, 2007, 140, 164-175.

17 M. A. Kashem and B. R. Singh, Nutr. Cycl. Agroecosys., 2001, 61, 247-255.

18 J.-H. Huang, S.-H. Hsu and S.-L. Wang, J. Hazard. Mater., 2011, 186, 1801-1807.

19 ANPM, Report on the state of environmental factors in Harghita county - 2007 (in Romanian), Ministry of the Environment and Durable Development, 2008.

20 MIPAF, Methods of chemical analysis of soil (in Italian), FrancoAngeli, Milan, Italy, 2000.

21 O. P. Mehra and M. L. Jackson, Clay Clay Miner., 1958, 7, 317-327.

22 M. O. Doyle and M. L. Otte, Environ. Pollut., 1997, 96, 1-11.

23 F. Liu, C. Colombo, P. Adamo, J. Z. He and A. Violante, Soil Sci. Soc. Am. J., 2002, 66, 661-670.

24 R. Balint, C. Orbeci, G. Nechifor, M. Plesca and F. Ajmone-Marsan, Rev. Chim. (Bucuresti), $2013,64,1218-1223$.

25 G. Rauret, J. F. López-Sánchez, A. Sahuquillo, E. Barahona, M. Lachica, A. M. Ure, C. M. Davidson, A. Gomez, D. Lück, J. Bacon, M. Yli-Halla, H. Muntau and P. Quevauviller, J. Environ. Monitor., 2000, 2, 228-233.

26 H. G. Kräutner, C. Udrescu and F. Gaftoi, Romanian J. Mineral Deposits, 1992, 75, 1-29.

27 I. Popescu, R. Nimirciag, G. Vina and F. Ajmone-Marsan, Rev. Chim. (Bucuresti), 2013b, 64, 477-481.

28 M. Davranche and J.-C. Bollinger, J. Colloid Interface Sci., 2000a, 227, 531-539.

29 M. Davranche and J.-C. Bollinger, J. Colloid Interface Sci., 2000b, 232, 165-173.

30 S. Cornu, J. A. Cattle, A. Samouëlian, C. Laveuf, L. R. G. Guilherme and P. Albéric, Soil Sci. Soc. Am. J., 2009, 73, 1231-1241.

31 K. R. Reddy and R. D. DeLaune, Biogeochemistry of wetlands: science and applications, CRC Press, Boca Raton, 2008.

32 P. Adamo, M. Zampella, L. Gianfreda, G. Renella, F. A. Rutigliano and F. Terribile, Environ. Pollut., 2006, 144, 308-316.

33 L. Van Laer, F. Degryse, K. Leynen and E. Smolders, Eur. J. Soil Sci., 2010, 61, 1014-1024.

34 F. M. G. Tack, E. Van Ranst, C. Lievens and R. E. Vandenberghe, Geoderma, 2006, 137, 83-89.

35 E. Donner, M. McLaughlin, M. Hodson, D. Heemsbergen, M. J. Warne, S. Nortcliff and K. Broos, Plant Soil, 2012, 361, 83-95.

36 P. Sipos, T. Németh, V. K. Kis and I. Mohai, Chemosphere, 2008, 73, 461-469. 
37 B. Fulda, A. Voegelin, F. Maurer, I. Christl and R. Kretzschmar, Environ. Sci. Technol., 47, 10903-10911.

38 C. J. Matocha, A. D. Karathanasis, S. Rakshit and K. M. Wagner, J. Environ. Qual., 2005, 34, 1539-1546.

39 Y. Li, N. Kawashima, J. Li, A. P. Chandra and A. R. Gerson, Adv. Colloid Interface Sci., 2013, 197$198,1-32$

40 L. Q. Ma and Y. Dong, Environ. Pollut., 2004, 130, 301-307.

41 M. Grybos, M. Davranche, G. Gruau and P. Petitjean, J. Colloid Interface Sci., 2007, 314, 490501.

42 F. X. Han, A. Banin and G. B. Triplett, Soil Sci., 2001, 166, 18-28.

43 D. Businelli, L. Massaccesi, D. Said-Pullicino and G. Gigliotti, Sci. Total Environ., 2009, 407, 1426-1435.

44 R. G. McLaren and D.V. Crawford, J. Soil Sci., 1973, 24, 172-181.

45 M. Pueyo, J. Mateu, A. Rigol, M. Vidal, J. F. López-Sánchez and G. Rauret, Environ. Pollut., $2008,152,330-341$. 
Table 1. Main physico-chemical properties of the studied soils.

\begin{tabular}{lccc}
\hline & HCN & LCN & NCN \\
\hline $\mathrm{pH}_{\mathrm{KCl}}$ & 5.0 & 5.1 & 5.1 \\
$\mathrm{C}_{\text {org }}\left(\mathrm{g} \mathrm{kg}^{-1}\right)$ & 37 & 39 & 35 \\
$\mathrm{~N}_{\text {tot }}\left(\mathrm{g} \mathrm{kg}^{-1}\right)$ & 3 & 4 & 3 \\
$\mathrm{Fe}\left(\mathrm{g} \mathrm{kg}^{-1}\right)$ & 42 & 44 & 23 \\
$\mathrm{Mn}\left(\mathrm{mg} \mathrm{kg}^{-1}\right)$ & 1487 & 1140 & 1134 \\
$\mathrm{Cu}\left(\mathrm{mg} \mathrm{kg}^{-1}\right)$ & 102 & 92 & 18 \\
$\mathrm{~Pb}\left(\mathrm{mg} \mathrm{kg}^{-1}\right)$ & 46 & 37 & 33 \\
$\mathrm{Zn}\left(\mathrm{mg} \mathrm{kg}^{-1}\right)$ & 148 & 130 & 111 \\
$\mathrm{Clay}\left(\mathrm{g} \mathrm{kg}^{-1}\right)$ & 29 & 43 & 83 \\
Silt $\left(\mathrm{g} \mathrm{kg}^{-1}\right)$ & 277 & 354 & 480 \\
Texture (ISSS) & sandy loam & loam & silt loam \\
\hline
\end{tabular}


Table 2. Metal concentrations in DCB and AO soil extracts of contaminated (HCN, LCN) and non-contaminated (NCN) soils. Values represent mean metal concentrations \pm standard deviation and values in parenthesis represent metal concentrations expressed as a percentage of pseudo-total contents reported in Table 1.

\begin{tabular}{|c|c|c|c|c|c|c|}
\hline & \multicolumn{2}{|c|}{$\mathrm{HCN}$} & \multicolumn{2}{|c|}{$\mathrm{LCN}$} & \multicolumn{2}{|c|}{ NCN } \\
\hline & $\mathrm{DCB}^{a}$ & $\mathrm{AO}^{b}$ & $\mathrm{DCB}$ & $\mathrm{AO}$ & $\mathrm{DCB}$ & $\mathrm{AO}$ \\
\hline $\mathrm{Fe}\left(\mathrm{g} \mathrm{kg}^{-1}\right)$ & $11.5 \pm 0.3(27)$ & $5.0 \pm 0.2(12)$ & $12.3 \pm 0.2(28)$ & $5.7 \pm 0.2(13)$ & $11.7 \pm 0.4(52)$ & $3.2 \pm 0.1(14)$ \\
\hline $\mathrm{Mn}\left(\mathrm{mg} \mathrm{kg}^{-1}\right)$ & $652 \pm 15(44)$ & $519 \pm 13(35)$ & $794 \pm 9(70)$ & $533 \pm 11(47)$ & $957 \pm 54(84)$ & $685 \pm 50(60)$ \\
\hline $\mathrm{Cu}\left(\mathrm{mg} \mathrm{kg}^{-1}\right)$ & $22 \pm 1(22)$ & $56 \pm 3(55)$ & $16 \pm 1(18)$ & $49 \pm 1(53)$ & $1 \pm 0(5)$ & $6 \pm 0(35)$ \\
\hline $\mathrm{Pb}\left(\mathrm{mg} \mathrm{kg}^{-1}\right)$ & $9 \pm 1(20)$ & b.d.l. ${ }^{c}$ & $4 \pm 1(11)$ & b.d.l. & b.d.l. & b.d.l. \\
\hline $\mathrm{Zn}\left(\mathrm{mg} \mathrm{kg}^{-1}\right)$ & $78 \pm 1(53)$ & $23 \pm 2(16)$ & $67 \pm 2(52)$ & $12 \pm 1(9)$ & $68 \pm 4(61)$ & $12 \pm 0(11)$ \\
\hline
\end{tabular}

${ }^{a}$ Dithionite-citrate-bicarbonate. ${ }^{b}$ Ammonium oxalate. ${ }^{c}$ Below detection limit. 
Table 3. Distribution of metals among fractions of the BCR sequential extraction of contaminated (HCN, LCN) and non-contaminated (NCN) soils. Values represent mean metal concentrations \pm standard deviation.

\begin{tabular}{|c|c|c|c|c|c|c|c|c|c|c|c|c|}
\hline \multirow{2}{*}{$\begin{array}{l}\text { BCR } \\
\text { step }\end{array}$} & \multicolumn{4}{|c|}{$\mathrm{HCN}$} & \multicolumn{4}{|c|}{ LCN } & \multicolumn{4}{|c|}{ NCN } \\
\hline & $\left.\right|^{a}$ & $\mathrm{U}^{b}$ & $\mathrm{~L}^{c}$ & $\mathrm{~B}^{d}$ & I & $U$ & $\mathrm{~L}$ & B & 1 & $U$ & $\mathrm{~L}$ & B \\
\hline & \multicolumn{12}{|c|}{$\mathrm{Zn}\left(m g \mathrm{~kg}^{-1}\right)$} \\
\hline F1 & $11.9 \pm 3.3$ & $4.4 \pm 0.6$ & $5.4 \pm 0.9$ & $3.7 \pm 0.4$ & $3.9 \pm 0.6$ & $2.0 \pm 0.4$ & $2.0 \pm 0.2$ & $1.8 \pm 0.1$ & $8.4 \pm 0.7$ & $6.7 \pm 0.3$ & $6.7 \pm 0.4$ & $7.1 \pm 0.2$ \\
\hline F2 & $18.5 \pm 1.9$ & $15.2 \pm 0.6$ & $18.2 \pm 0.8$ & $15.8 \pm 0.9$ & $10.5 \pm 0.9$ & $8.5 \pm 1.1$ & $8.7 \pm 1.7$ & $7.6 \pm 0.8$ & $9.6 \pm 0.4$ & $8.7 \pm 0.5$ & $9.3 \pm 1.4$ & $8.6 \pm 0.7$ \\
\hline F3 & $13.6 \pm 0.8$ & $13.9 \pm 1.3$ & $15.1 \pm 2.6$ & $16.6 \pm 3.6$ & $9.2 \pm 0.3$ & $9.1 \pm 0.7$ & $8.4 \pm 1.2$ & $8.3 \pm 1.0$ & $10.9 \pm 0.3$ & $11.0 \pm 0.4$ & $10.8 \pm 0.9$ & $10.4 \pm 0.3$ \\
\hline F4 & $\begin{array}{l}108.7 \pm \\
12.0\end{array}$ & $\begin{array}{l}117.4 \pm \\
7.2\end{array}$ & $\begin{array}{l}109.4 \pm \\
2.9\end{array}$ & $113.7 \pm 7.5$ & $94.8 \pm 7.8$ & $91.4 \pm 1.7$ & $90.9 \pm 2.1$ & $90.2 \pm 2.4$ & $73.0 \pm 1.0$ & $79.3 \pm 5.3$ & $78.8 \pm 1.9$ & $78.0 \pm 5.3$ \\
\hline Sum & $\begin{array}{l}152.7 \pm \\
18.0\end{array}$ & $\begin{array}{l}150.9 \pm \\
9.7\end{array}$ & $\begin{array}{l}148.1 \pm \\
7.2\end{array}$ & $\begin{array}{l}149.8 \pm \\
12.4\end{array}$ & $\begin{array}{l}118.4 \pm \\
9.6\end{array}$ & $\begin{array}{l}111.0 \pm \\
3.9\end{array}$ & $\begin{array}{l}110.0 \pm \\
5.2\end{array}$ & $\begin{array}{l}107.9 \pm \\
4.3\end{array}$ & $\begin{array}{l}101.9 \pm \\
2.4\end{array}$ & $\begin{array}{l}105.7 \pm \\
6.5\end{array}$ & $105.6 \pm 4.6$ & $\begin{array}{l}104.1 \pm \\
5.3\end{array}$ \\
\hline & \multicolumn{12}{|c|}{$\mathrm{Cu}\left(\mathrm{mg} \mathrm{kg}^{-1}\right)$} \\
\hline F1 & $4.2 \pm 0.3$ & $6.0 \pm 0.2$ & $8.8 \pm 0.3$ & $6.7 \pm 0.5$ & $2.4 \pm 0.3$ & $3.2 \pm 0.5$ & $5.8 \pm 0.8$ & $5.8 \pm 0.6$ & b.d.l.e & b.d.l. & b.d.l. & b.d.l. \\
\hline $\mathrm{F} 2$ & $41.3 \pm 0.8$ & $35.3 \pm 0.5$ & $34.6 \pm 0.3$ & $33.4 \pm 1.2$ & $29.7 \pm 0.5$ & $24.4 \pm 1.1$ & $25.0 \pm 0.4$ & $24.8 \pm 0.5$ & $1.5 \pm 0.2$ & $1.5 \pm 0.2$ & $1.5 \pm 0.1$ & $1.7 \pm 0.2$ \\
\hline F3 & $17.2 \pm 0.5$ & $14.9 \pm 1.5$ & $13.5 \pm 1.1$ & $13.9 \pm 1.7$ & $8.8 \pm 0.5$ & $7.2 \pm 1.2$ & $5.6 \pm 0.6$ & $5.4 \pm 0.3$ & b.d.l. & b.d.I. & b.d.I. & b.d.l. \\
\hline F4 & $40.3 \pm 1.4$ & $47.1 \pm 2.4$ & $40.3 \pm 1.5$ & $44.4 \pm 2.4$ & $43.4 \pm 2.7$ & $42.1 \pm 1.5$ & $38.6 \pm 0.9$ & $37.4 \pm 2.7$ & $11.7 \pm 0.0$ & $12.5 \pm 0.3$ & $12.1 \pm 0.6$ & $12.3 \pm 0.5$ \\
\hline Sum & $103.0 \pm 3.0$ & $\begin{array}{l}103.3 \pm \\
4.6\end{array}$ & $97.2 \pm 3.2$ & $98.4 \pm 5.8$ & $84.3 \pm 4.0$ & $76.9 \pm 4.3$ & $75.0 \pm 2.7$ & $73.4 \pm 4.1$ & $13.2 \pm 0.2$ & $14.0 \pm 0.5$ & $13.6 \pm 0.7$ & $14.0 \pm 0.7$ \\
\hline & \multicolumn{12}{|c|}{$P b\left(m g k g^{-1}\right)$} \\
\hline F1 & b.d.l. & b.d.I. & b.d.l. & b.d.l. & b.d.l. & b.d.I. & b.d.I. & b.d.l. & b.d.l. & b.d.l. & b.d.l. & b.d.l. \\
\hline $\mathrm{F} 2$ & $22.2 \pm 1.9$ & $22.4 \pm 1.3$ & $23.3 \pm 1.4$ & $23.2 \pm 1.4$ & $12.4 \pm 0.2$ & $10.9 \pm 1.6$ & $11.3 \pm 1.8$ & $11.5 \pm 0.4$ & $11.5 \pm 1.3$ & $14.4 \pm 2.8$ & $17.3 \pm 2.6$ & $13.7 \pm 1.7$ \\
\hline F3 & b.d.l. & b.d.l. & b.d.l. & b.d.l. & b.d.l. & b.d.l. & b.d.I. & b.d.l. & b.d.l. & b.d.l. & b.d.l. & b.d.l. \\
\hline F4 & $21.6 \pm 1.9$ & $22.5 \pm 1.8$ & $22.1 \pm 1.4$ & $23.3 \pm 1.1$ & $22.8 \pm 5.7$ & $16.6 \pm 0.9$ & $16.1 \pm 1.0$ & $16.1 \pm 2.6$ & $16.5 \pm 0.4$ & $14.9 \pm 2.0$ & $15.6 \pm 2.7$ & $18.2 \pm 2.4$ \\
\hline Sum & $43.8 \pm 3.8$ & $44.9 \pm 3.1$ & $45.4 \pm 2.8$ & $46.5 \pm 2.5$ & $35.2 \pm 5.9$ & $27.5 \pm 2.5$ & $27.4 \pm 2.8$ & $27.6 \pm 3.0$ & $28.0 \pm 1.7$ & $29.3 \pm 4.8$ & $32.9 \pm 5.3$ & $31.9 \pm 4.1$ \\
\hline
\end{tabular}

\footnotetext{
${ }^{a}$ Initial soil. ${ }^{b}$ Upper soil layer. ${ }^{c}$ Lower soil layer. ${ }^{d}$ Bottom soil layer. ${ }^{e}$ Below detection limit.
} 


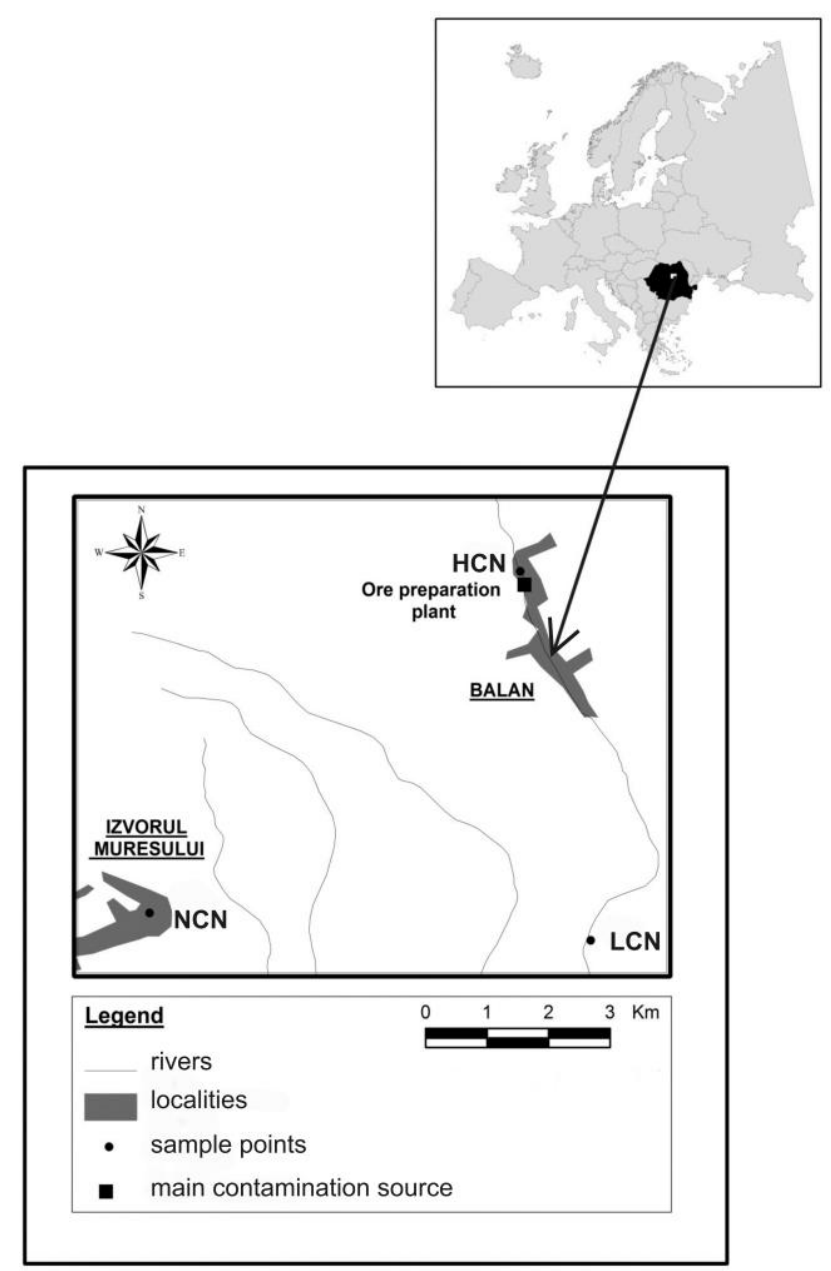

Fig. 1. Schematic map of the studied area. HCN - highly contaminated soil; LCN - low contaminated soil; NCN - non-contaminated soil. 


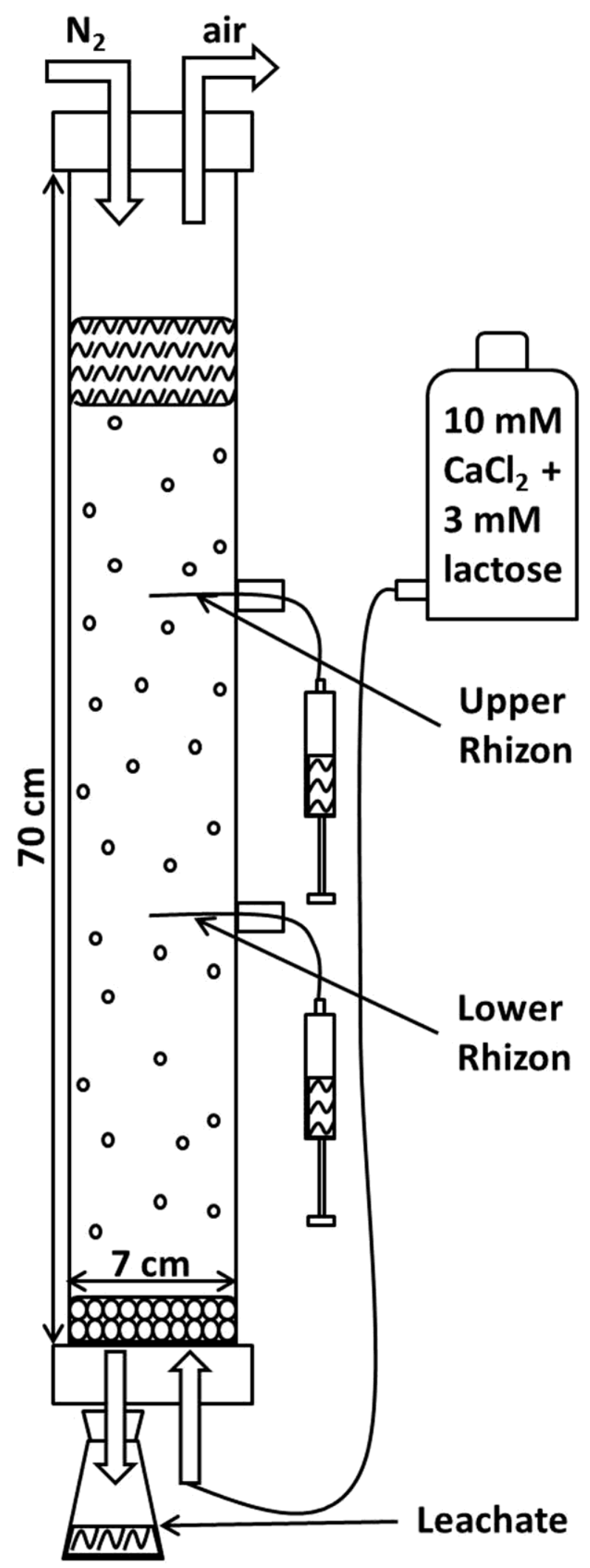

Fig. 2. Sketch of the column experimental setup. Adapted from Balint et al. ${ }^{24}$ 


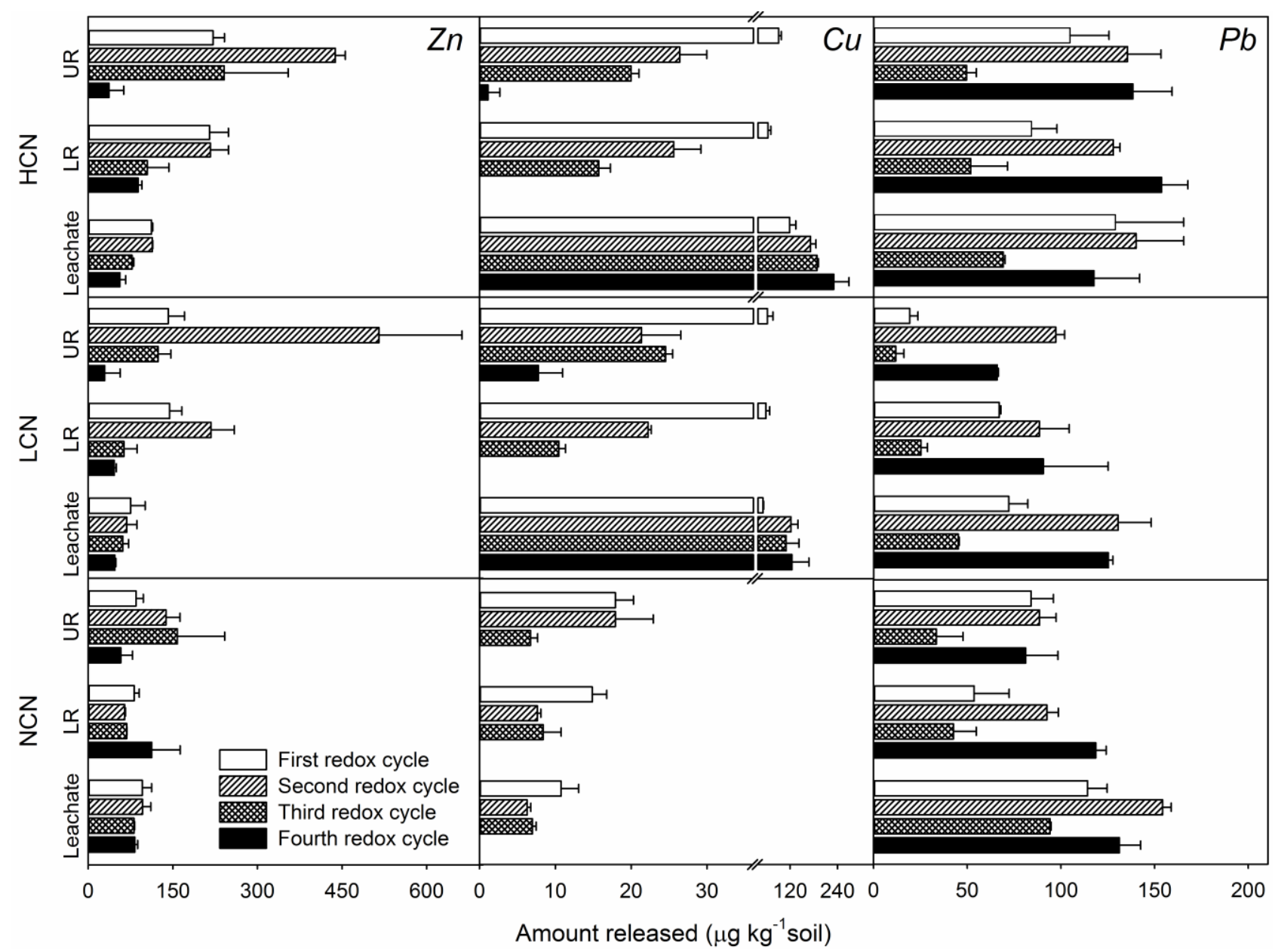

Fig. 3. Amount of $\mathrm{Zn}, \mathrm{Cu}$ and $\mathrm{Pb}$ and released in solution, as extracted by Rhizon samplers and leached through the column in the four redox cycles. UR, LR - soil solution sampled with the upper and lower Rhizon, respectively. Leachate - soil solution drained from the column. HCN, LCN, and NCN - highly, low, and non-contaminated soil, respectively. Note the break in the scale of $\mathrm{Cu}$. Error bars represent standard deviations. 

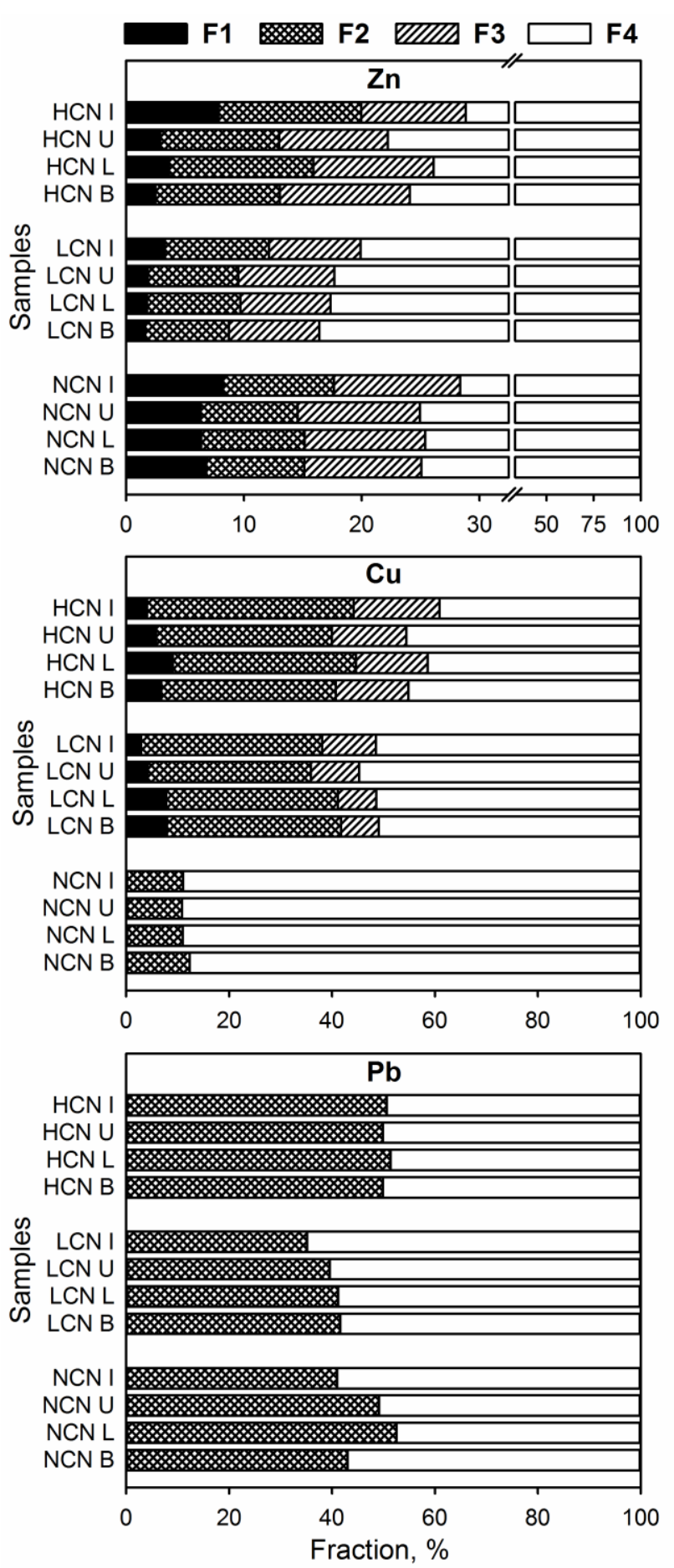

Fig. 4. BCR metal fractionation performed on initial (I) and column-incubated soil (U, L, B - upper, lower, and bottom layers, respectively) after 4 redox cycles. HCN, LCN, and NCN - highly, low, and non-contaminated soil, respectively. Note the break in the fraction scale of $\mathrm{Zn}$. 